\title{
DETERMINATION OF PATHOGEN RESISTANCE TO STREPTOMYCIN
}

\author{
Lecturer Anca CHEREJI*, PhD \\ Rareş CHEREJI^*, DVM
}

\begin{abstract}
This research was made in order to emphasize the actual incindence of the sensibility of various bacterial pathogens to streptomycin. The pathogens were identified as belonging to Staphylococcus, Escherichia, Citrobacter, Enterobacter, Klebsiella, Salmonella, Proteus, Pasteurella and Pseudomonas genus.

Antimicrobial agar disk diffusion method was used to test the strains isolated from animals and the results were interpreted as resistant, intermediate and sensitive according to international standards.

Resistance in 100\% percentage was registered for staphylococci and also for the pathogens from Citrobacter, Enterobacter, Proteus, Pasteurella, Pseudomonas genus. There wasalso resistance for Escherichia coli strains - 90\%, and Salmonella - 50\%.

Intermediary values of the antibacterial inhibition zones presented Salmonella (50\%) and also Escherichia coli pathogens (10\%).

The only genus that was sensitive to streptomycin was Klebsiella.

The frequency of resistance phenomenon to streptomycin was $87,5 \%$, intermediary values for the inhibition zones $-8,33 \%$ and only $4,17 \%$ of the strains showed sensibility to this antibiotic.
\end{abstract}

Keywords: pathogen resistance, streptomycin

\section{Introduction}

Aminoglycosides represent, next to betalactamines, the group of antibiotics having the larger therapeutical use. The first discovered aminoglycosides were natural molecules, produced by Streptomyces (streptomycin, neomycin, kanamycin, tobramycin) or Micromonospora (gentamycin, sisomycin).

Streptomycin and dihydrostreptomycin have a relatively restricted spectrum, the resistance being very spread between these antibiotics. Nevertheless, there a few staphylococci, even some streptococci and gram-negative bacilli still sensitive, among these Actinomyces bovis strains, Pasteurella spp, E. coli, Salmonella spp., Campylobacter fetus, Leptospira spp. and Brucella spp.. Mycobacterium tuberculosis, also, is still sensitive to streptomycin (Vakurenko S.B. and Mobashery S., 2003).

Starting with natural aminoglycosides, there were later conceived, using semisynthesis technique, molecules less sensitive to enzyme inactivation induced by resistant bacteria and having lower toxicity (amikacin, netilmycin etc.) (Oniga O. and Tiperciuc Brânduşa, 2003).

\footnotetext{
* University of Agricultural Sciences and Veterinary Medicine Cluj-Napoca, Faculty of Veterinary Medicine, Department of Pharmacology, 3-5 Mănăştur Street, 400372 Cluj-Napoca
}

** S.C. Biovet Serv. S.R.L., Cluj Napoca

Cluj Veterinary Journal, 15(1)/2009, pp. 69-72 
This study was made in order to investigate the present resistance of some pathogens to streptomycin, taking into account the fact that aminoglycosides are used, despite their high nephrotoxicitiy, to control local and systemic infections due to sensitive aerobic bacteria (generally gram-negative) (Cristina T. Romeo, 2006). The aminoglycosides recommendation is justified by their therapeutical efficiency (Mărculescu Anca, 2007).

\section{Material and Methods}

The sensibility of a pathogen to antibiotics can be tested through a relative unsophisticated method - the antibiogram.

The materials used in this study were represented by bacterial strains, cuture media and disks with a standard quantity of antibiotic.

The bacterial strains were isolated from abscesses, phlegmons, vaginal secretions, secretions mastitis, faeces, intestinal contents, organs with lesions (liver, spleen, heart, lungs, nodules etc.), bones and corpses of animals.

The susceptibility to streptomycin was tested on 48 gram-positive and gram-negative bacterial strains.

The cultivation was made on usual media (broth and agar) with a plus of serum, glucose, blood when necessary, or special media (Răpuntean Gh. and Boldizsar E., 2001).

The interpretation of the antimicrobial agar disk diffusion method had been effected according to international standards (NCCLS M31-A, M31-T, 1999).

\section{Results and Discussions}

A number of 48 pathogens from Staphylococcus, Escherichia, Citrobacter, Enterobacter, Klebsiella, Salmonella, Proteus, Pasteurella, Pseudomonas genus was investigated through antibiogram in order to determine the sensitivity to streptomycin.

The results were interpreted (table 1) and the pathogens were noted as resistant (R), sensible (S) or with intermediary values (I) to this antibiotic (table 2).

Table1. Disc diffusion test interpretation according to international standards

\begin{tabular}{|c|c|c|c|c|c|c|}
\hline Crt. & \multirow{2}{*}{$\begin{array}{c}\text { Antibiotic } \\
\text { no. }\end{array}$} & Atb/conc. & \multicolumn{4}{|c|}{ Diametrul zonei de inhibiție antibacteriană (mm) } \\
\cline { 4 - 7 } & disc & $\mathrm{R}$ & $\mathrm{I}$ & $\mathrm{S}$ & \multicolumn{1}{c|}{ Standard values: } \\
\hline & Streptomicină & $100 \mu \mathrm{g}$ & $\leq 22$ & $23-25$ & $\geq 26$ & Neo-Sensitab Veterinary Pathogens -NCCLS \\
& & & & & & \\
\hline
\end{tabular}

Table 2. Susceptibility/resistance to streptomycin

\begin{tabular}{|c|l|c|c|c|c|c|c|c|}
\hline \multirow{2}{*}{$\begin{array}{c}\text { Crt. } \\
\text { no. }\end{array}$} & \multirow{2}{*}{ Bacterial strains } & \multirow{2}{*}{ No. } & \multicolumn{7}{|c|}{ Sensibility/resistance } \\
\cline { 5 - 9 } & & & $\mathbf{R}$ & $\%$ & $\mathbf{I}$ & $\%$ & $\mathbf{S}$ & $\%$ \\
\hline 1 & Staphylococcus & 6 & 6 & 100 & - & - & - & - \\
\hline 2 & E. coli & 20 & 18 & 90 & 2 & 10 & - & - \\
\hline 3 & Citrobacter & 2 & 2 & 100 & - & - & - & - \\
\hline 4 & Enterobacter & 2 & 2 & 100 & - & - & - & - \\
\hline 5 & Klebsiella & 2 & - & - & - & - & 2 & 100 \\
\hline 6 & Salmonella & 4 & 2 & 50 & 2 & 50 & - & - \\
\hline 7 & Proteus & 4 & 4 & 100 & - & - & - & - \\
\hline 8 & Pasteurella & 2 & 2 & 100 & - & - & - & - \\
\hline 9 & Pseudomonas & 6 & 6 & 100 & - & - & - & - \\
\hline
\end{tabular}


Many attainment mechanisms of resistance to streptomycin were described; can be plasmid mediated or owed to mutations. A non-plasmid mediated mechanism is the decrease of the transportation through cellular membrane. The anaerobic (Clostridium) and facultative anaerobic (enterobacteriaceae and some staphylococci) bacteria are more resistant to aminoglycosides, in an anaerobic medium, because of the active and oxygen-dependent transportation.

A $100 \%$ resistance of staphylococci can be observed in the antibiograms of the present study. The resistance due to decreased carriage can be induced by the exposal of bacterial strains to sublethal concentrations of antibiotic. An example is the Pseudomonas aeruginosa resistance to streptomycin, as it is obvious also in the tested strains of this research.

The decreasing of the binding of antibiotic to ribosomes is also a mechanism of Pseudomonas resistance to streptomycin; that type of mechanism is met also in Escherichia coli strains. Furthermore, the results of the present study show a 100\% percentage of resistance in Pseudomonas, whilst in the case of Escherichia coli - a 90\% resistance and 10\% intermediary values of the antibacterial inhibition zones; as some authors point out (Angelescu M., 1998), that means also 100\% resistance, because mostly statistical and epidemiological studies present the existence only of resistant and sensible strains.

Even if Ray A. et al, in 2006, observe in Salmonella genus the highest resistance to streptomycin, in this research there are only $50 \%$ of resistant strains; all the same, because of the existence of a great number of intermediate strains $-50 \%$, the sensitivity of the pathogens to this antibiotic is $0 \%$.

The resistance emerge also through an enzymatic mechanism. These enzymes are found both in gram-negative and gram-positive bacteria. It is possible that this mechanism determined the resistance in all strains from Citrobacter, Enterobacter, Proteus şi Pasteurella genus, as it is showed in graphic 1 .

Accordingly, it is observed that for streptomycin the antibiotic resistance phenomenon appear in a rather high percentage $-87,5 \%$, as we marked for 21 of the 24 tested strains, being in existence also a percentage of $8,33 \%$ of intermediary values -2 strains, and only one strain was sensitive - a percentage of $4,17 \%$ of the total strains (graphic 2).

\section{Conclusions}

Bacterial strains from Staphylococcus, Escherichia, Citrobacter, Enterobacter, Klebsiella, Salmonella, Proteus, Pasteurella, Pseudomonas genus were investigated about the susceptibility

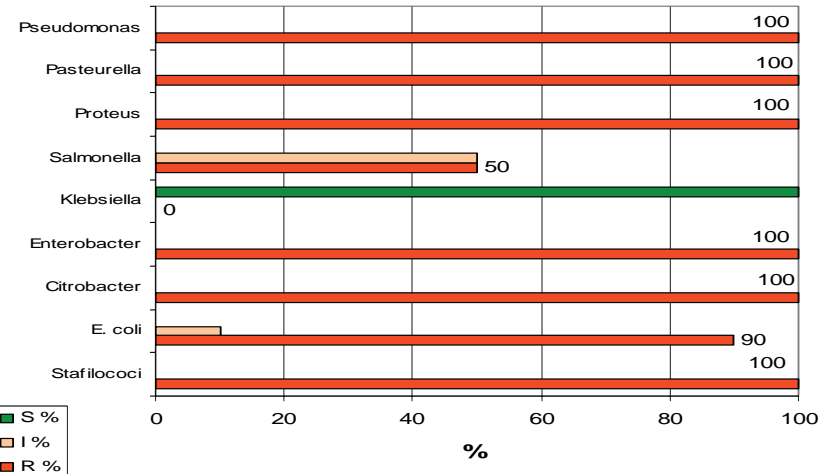

Graphic 1. Resistance to streptomycin

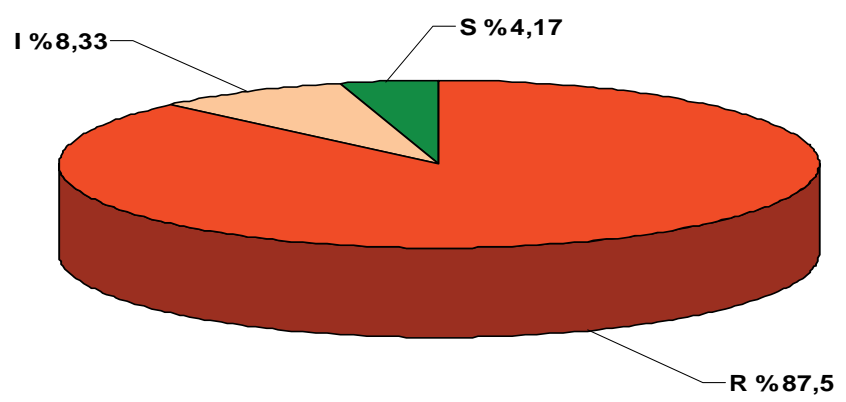

Graphic 2. The frequentness of resistance phenomenon to streptomycin to streptomycin;

The antimicrobial agar disk diffusion method was used for the testing of the pathogens;

The results were interpreted according to international standards;

Staphylococci registered a 100\% resistance to streptomycin and also Citrobacter, Enterobacter, Proteus, Pasteurella, Pseudomonas strains; 
Escherichia coli strains showed also rather high percentage of resistance to this antibiotic - 90\%, the rest of $10 \%$ being intermediary values of the inhibition zones

Resistance of $50 \%$ was observed for Salmonella pathogens and intermediary values, also in $50 \%$ percentage

The only genus that was sensitive to streptomycin was Klebsiella;

The resistance of the investigated pathogens was, generally, 87,5\%, being noted intermediary values $-8,33 \%$ and only $4,17 \%$ of the strains showed sensibility to this antibiotic.

\section{References}

1. Angelescu Mircea - Terapia cu antibiotice, Ed. Medicală, Bucureşti, 1998;

2. Cristina T. Romeo - Bazele Farmacologiei Veterinare, Ed. Brumar, Timişoara, 2000;

3. Mărculescu Anca - PhD Thesis: „Studiu privind evoluţia fenomenului de antibiorezistenţă şi posibilitatea diminuării acestuia prin asocierea de antibiotice, pe baza relaţiilor de sinergism”, Universitatea de Ştiinţe Agricole şi Medicină Veterinară Cluj-Napoca, 2007

4. NCCLS, M31-A - Performance Standards for Antimicrobial Disk and Dilution Susceptibility Tests for Bacteria Isolated from Animals; Approved Standard, 1999, vol.19, No. 11;

5. NCCLS, M31-T - Performance Standards for Antimicrobial Disk and Dilution Susceptibility Tests for Bacteria Isolated from Animals; Approved Standard, 1999, vol.17, No. 11;

6. Oniga O., Brînduşa Tiperciuc - Antibiotice Antibacteriene, Editura Medicală Universitară „Iuliu Haţieganu", Cluj-Napoca, 2003;

7. Ray K.A., L.D. Warnick, R.M. Michell, J.B. Kaneene, P.L. Ruegg, S.J. Wells, C.P. Fossier, L.W. HalbertAntimicrobial susceptibility of Salmonella from organic and conventional daily farm, J. Dairy Sci., 2006, 89 (6): 2038-50;

8. Răpuntean Gh., Boldizsar E. - Practicum de Bacteriologie Specială, Ed. AcademicPres, Cluj-Napoca, 2001;

9. Vakurenko S.B., S. Mobashery - Versatility of aminoglycosides and prospects for their future, Clinical Microbiol. Reviews, 2003, vol. 16, 430-450; 